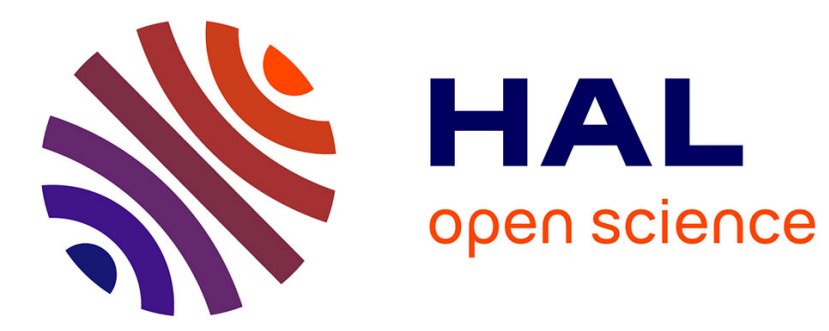

\title{
Americium, curium and neodymium analysis in ECRIX-H irradiated pellet: sample preparation for TIMS measurements
}

Eric Esbelin, E. Buravand, S. Bejaoui, J. Lamontagne, J. M Bonnerot

\section{To cite this version:}

Eric Esbelin, E. Buravand, S. Bejaoui, J. Lamontagne, J. M Bonnerot. Americium, curium and neodymium analysis in ECRIX-H irradiated pellet: sample preparation for TIMS measurements. Radiochimica Acta, 2013, 101 (5), pp.293-300. 10.1524/ract.2013.2038 . cea-02267580

HAL Id: cea-02267580

https://hal-cea.archives-ouvertes.fr/cea-02267580

Submitted on 19 Aug 2019

HAL is a multi-disciplinary open access archive for the deposit and dissemination of scientific research documents, whether they are published or not. The documents may come from teaching and research institutions in France or abroad, or from public or private research centers.
L'archive ouverte pluridisciplinaire HAL, est destinée au dépôt et à la diffusion de documents scientifiques de niveau recherche, publiés ou non, émanant des établissements d'enseignement et de recherche français ou étrangers, des laboratoires publics ou privés. 


\title{
Americium, curium and neodymium analysis in ECRIX-H irradiated pellet: sample preparation for TIMS measurements
}

\author{
By E. Esbelin ${ }^{1, *}$, E. Buravand ${ }^{1}$, S. Béjaoui ${ }^{2}$, J. Lamontagne ${ }^{2}$ and J. M. Bonnerot ${ }^{2}$ \\ ${ }^{1}$ Commissariat à l'Énergie Atomique, Centre de Marcoule, 30207, Bagnols-sur-Cèze, France \\ ${ }^{2}$ Commissariat à l'Énergie Atomique, Centre de Cadarache, 13108 St-Paul-Lez-Durance, France
}

(Received June 29, 2012; accepted in revised form November 21, 2012)

(Published online April 22, 2013)

\section{Americium / Curium / Neodymium / HPLC / Chromatography / Isotopic dilution}

Summary. This paper concerns quantitative isotopic analysis of $\mathrm{Am}, \mathrm{Cm}$ and $\mathrm{Nd}$ contained in an irradiated $\mathrm{AmO}_{1.62} / \mathrm{MgO}$ pellet. The complete analysis protocol is described, from dissolution of the pellets in a shielded line to the laboratory glove separation processes box for TIMS analysis. Emphasis is placed on the separation processes: by ion exchange resin in a hot cell and by HPLC in the laboratory. Intermediate measurements by X-ray fluorescence, alpha spectrometry, and ICP-AES are described.

\section{Introduction}

The primary objective of the ECRIX-H experiment was to assess the feasibility of transmuting americium microdispersed in an inert magnesia matrix $\left(\mathrm{AmO}_{1.62} / \mathrm{MgO}\right)$ in heterogeneous mode in a partially moderated neutron flux in the Phenix reactor. Numerous characterizations were achieved on irradiated material by nondestructive measurements (visual inspection, metrology, gamma spectrometry, Eddy current testing [1-3]), and by destructive measurements (gas analyses, hydrostatic density measurements, scanning electron microscopy (SEM) [3], X-ray diffraction (XRD) [3], secondary ion mass spectroscopy (SIMS) [4], electron probe microanalysis (EPMA) [4]).

Among the destructive measurements, elemental and isotopic characterization of $\mathrm{Am}, \mathrm{Cm}$ and $\mathrm{Nd}$ in an irradiated ECRIX-H pellet were carried out by the Analysis and Material Metrology Laboratory (LAMM) in the CEA Atalante complex at Marcoule. This work is the subject of this paper.

The LAMM laboratory performs analyses for R\&D studies in Atalante, which frequently include high-activity analyses of spent fuel dissolution solutions.

Direct high-activity analyses requiring no sample preparation but which are subject to uncertainty of up to $30 \%$ can be distinguished from indirect analyses after sample treatment for much more precise analytical techniques that are not available in a high-activity environment.

Laboratory analysis of the intermediate-level solutions derived from high-level operations depends on the dilution

*Author for correspondence (E-mail: eric.esbelin@cea.fr). and/or decontamination factor to ensure that the sample activity and dose rate are compatible with safety standards for glove box work. When the analyte is present at low concentrations in the dissolution solution, the dilution factor is sometimes such that even the techniques with the lowest detection limits are ineffective. Separation techniques are then necessary for selective extraction of the analyte.

This article describes the steps required in the intermediate-level laboratory to obtain samples meeting the prerequisites for TIMS analysis. The results obtained are compared with the values calculated from neutronic simulation codes.

\section{About neutronic simulations}

ECRIX-H neutronic simulations were performed by using GEPHIX and CESAR calculation codes [5] devoted to the management of the PHENIX plant. Complementary simulations were also performed using the ERANOS and DARWIN codes [6] to obtain a more detailed description of fuel evolution during irradiation, including its composition in terms of helium and fission products.

Pellets on which chemical measurements were performed received about $95 \%$ of the overall fluence at the maximum flux plane. Based on the neutronic simulations, polynomial and linear interpolations of transmutation and fission rates were determined as a function of the reveived fluence. Using these interpolations, transmutation and fission rates can be extrapolated to account for the fluence at the maximum flux plan. Transmutation rate at the maximum flux plane is estimated to $94.3 \%$.

\section{Sample preparation for TIMS analysis}

\subsection{Experimental}

The dissolution solutions were filtered by means of a vacuum filtration system with $0.5 \mu \mathrm{m}$ PTFE filters.

Two types of resin were tested:

- Biorad AG1X8 with a mean particle size of 74-149 $\mu \mathrm{m}$ : about $2.5 \mathrm{~mL}$ packed in glass columns $(4 \mathrm{~mm}$ diameter, $8 \mathrm{~cm}$ high) and equilibrated in $8 \mathrm{M}$ nitric acid. 


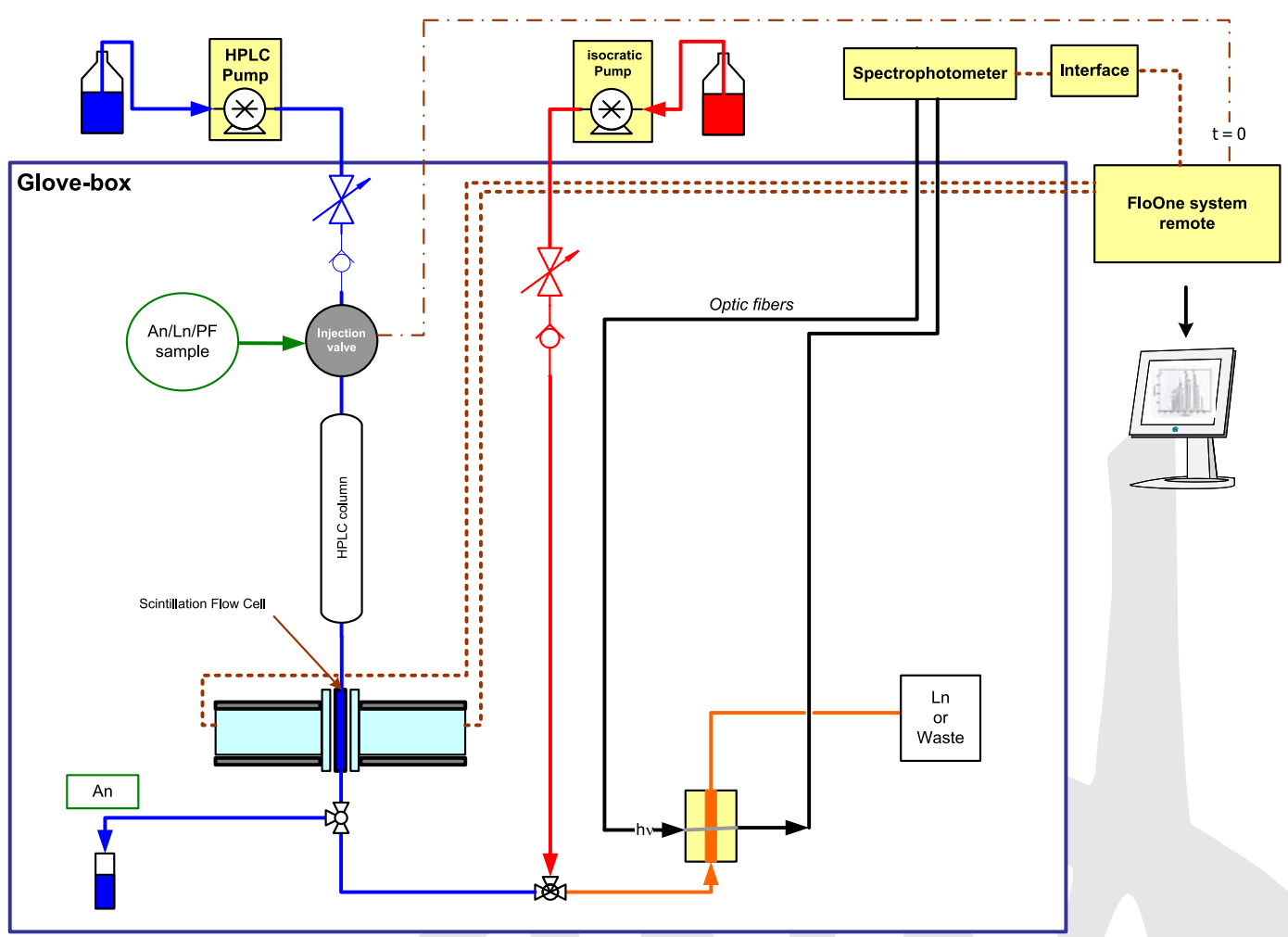

- Eichrom Normal DGA used in pre-packed $2 \mathrm{~mL}$ columns with a mean particle size of $50-100 \mu \mathrm{m}$. Each column was preconditioned with $8 \mathrm{~N}$ nitric acid.

Gravity elution was performed with AG1X8 resin. An Ismatec peristaltic pump with a tube diameter suitable for controlling the elution of about $1 \mathrm{~mL}$ was used in a shielded cell for separation on Eichrom resin.

Measurements in the hot cell were performed by gamma spectrometry (Canberra) and L-line X-ray fluorescence (LXF). The LXF system is an X-ray fluorescence instrument with a graphite monochromator used as a bandpass filter centered on the energy of the $14.3 \mathrm{keV}$ L-line of Pu.

Separations in the laboratory were carried out on a nuclearized glove-box HPLC system (Fig. 1) composed of an Agilent 1200 series quaternary pump, an Agilent 1200 series vacuum degasser, a Perkin-Elmer 610TR flow scintillation analyzer, an Ocean Optics HR4000 spectrophotometer, an Ocean Optics DH2000 light source, SEDI HCG400 optical fibers, and an Ocean optics $10 \mathrm{~mm} Z$-flow cell. A GV Instruments VG54 thermal ionization mass spectrometer (TIMS) was used. All reagents were analytical grade.

\subsection{Dissolution of irradiated pellets}

Two irradiated pellets were dissolved by the Laboratory for Dissolution Studies (LED) in the $\mathrm{C} 11 / \mathrm{C} 12$ shielded line of the Atalante complex (CEA Marcoule). The hot cell was cleaned prior to each dissolution by performing the dissolution protocol without any active material and analyzing the solution to evaluate the residual radioactivity level in the cell. The measured gamma activity was below $10^{-2} \%$ of the gamma activity of the dissolved pellet.

The mass of $\mathrm{AmO}_{1.62} / \mathrm{MgO}$ pellets for each dissolution was about $0.5 \mathrm{~g}$. At each step in the dissolution protocol, the exact masses were recorded (pellet mass, added nitric acid mass, etc.). The final dissolution solution volume was about $70 \mathrm{~mL}$.

\subsubsection{First dissolution}

The first dissolution was carried out for $4 \mathrm{~h}$ in boiling $4 \mathrm{~N}$ nitric acid. The dissolution solution was filtered; many undissolved particles visible to the naked eye were recovered on the filter. Dissolution was not complete, and therefore the solution characterization is not representative of the actual $\mathrm{Am}, \mathrm{Cm}$ and $\mathrm{Nd}$ concentrations in the pellet.

\subsubsection{Second dissolution}

The second dissolution was performed in a mixture of $4 \mathrm{~N}$ nitric acid and $0.1 \mathrm{~N}$ hydrofluoric acid, a chemically more aggressive solution, to ensure quantitative dissolution of the pellet. The insolubles recovered after filtration were washed with a solution of $11 \mathrm{~N} \mathrm{HNO}_{3}$ and $0.1 \mathrm{~N} \mathrm{HF}$ to eliminate any silica remaining from chemical etching of the glassware by hydrofluoric acid. The undissolved mass after scrubbing represented about $2.5 \mathrm{wt}$. \% of the irradiated pellet. Analysis of this solution yielded a quantitative assay of $97.5 \%$ of the dissolved pellet.

\subsection{Initial high-activity analyses}

Two filtered solution samples were sent by pneumatic transfer to the CBA shielded analysis line. The initial highactivity analyses were carried out without any prior sample treatment (Table 1) to obtain the approximate concentrations of the major elements of interest for comparison with the values estimated from neutronic simulation codes. This step was particularly important to finalize the development of the 
Table 1. First analyses in shielded line.

\begin{tabular}{llll}
\hline $\begin{array}{l}\text { Elements analyzed } \\
( \pm \text { measurement uncertainty) }\end{array}$ & $1^{\text {st }}$ dissolution & $2^{\text {nd }}$ dissolution & Analysis technique \\
\hline $\mathrm{U}( \pm 30 \%)$ & $6 \pm 2 \mathrm{mg} / \mathrm{L}$ & $25 \pm 8 \mathrm{mg} / \mathrm{L}$ & X-ray fluorescence ${ }^{a}$ \\
$\mathrm{Pu}( \pm 5 \%)$ & $138 \pm 7 \mathrm{mg} / \mathrm{L}$ & $807 \pm 40 \mathrm{mg} / \mathrm{L}$ & Spectrophotometry \\
$\mathrm{Am}( \pm 10 \%)$ & $17 \pm 2 \mathrm{mg} / \mathrm{L}$ & $97 \pm 10 \mathrm{mg} / \mathrm{L}$ & ICP-AES \\
$\mathrm{Nd}( \pm 10 \%)$ & $32 \pm 3 \mathrm{mg} / \mathrm{L}$ & $34 \pm 3 \mathrm{mg} / \mathrm{L}$ & ICP-AES \\
$\mathrm{H}^{+}( \pm 5 \%)$ & $3.8 \pm 0.2 \mathrm{M}$ & $4.3 \pm 0.2 \mathrm{M}$ & Potentiometry \\
Density $( \pm 5 \%)$ & $1.144 \pm 0.057 \mathrm{~g} / \mathrm{mL}$ & $1.154 \pm 0.058 \mathrm{~g} / \mathrm{mL}$ & Weighing \\
\hline
\end{tabular}

a: Because spectral interference, a selelective separation of $\mathrm{U}$ in a main $\mathrm{Pu}$ flow [7] was need.

Table 2. Comparative orders of magnitude of $\mathrm{U}, \mathrm{Pu}, \mathrm{Am}, \mathrm{Cm}$ and $\mathrm{Nd}$ concentrations between two dissolution solutions: UOX 2 (cooled for 5 years) and ECRIX-H (cooled for 3 years).

\begin{tabular}{llllrllll}
\hline \multicolumn{1}{c}{ Approximate concentration $(\mathrm{mg} / \mathrm{L})$} & & & Mass ratio & $\alpha$ activity ratio \\
\hline Solution & $\mathrm{U}$ & $\mathrm{Pu}$ & $\mathrm{Am}$ & $\mathrm{Cm}$ & $\mathrm{Nd}$ & $\mathrm{Mg}$ & $\mathrm{Am} / \mathrm{Cm}$ & $\mathrm{Cm} / \mathrm{Am}$ \\
UOX 2 & $235 \times 10^{3}$ & 2800 & 150 & 23 & 1340 & $\varepsilon$ & 6.5 & $\sim 4$ \\
ECRIX-H & 25 & 800 & 100 & 135 & 35 & 400 & 0.7 & $\sim 60$ \\
\hline
\end{tabular}

analysis protocols and to guarantee that the quantities implemented are sufficient for the intended analytical techniques. Moreover, these values were indispensable for defining the protocol for tracing the elements of interest in the dissolution solution.

The volumes of both dissolutions were practically the same, allowing the concentrations of the two columns to be compared. The U, $\mathrm{Pu}$ and Am concentrations are visibly much lower in the first dissolution solution than in the second: there ratio between the concentrations for $\mathrm{Pu}$ and $\mathrm{Am}$ was about $6: 1$ (only about $4: 1$ for $U$ ). These initial results suggest that Pu and Am (and U?) could be colocalized in the insolubles. This hypothesis was supported by electron probe microanalysis (EPMA) and X-ray diffraction (XRD) observations $[3,4]$ indicating colocalization of $\mathrm{Pu}, \mathrm{Am}$, and $\mathrm{Cm}$ in a $\mathrm{PuO}_{x}$ phase.

\subsubsection{Particularity of the matrix}

Based on the initial results in Table 1 and the values calculated from neutronic simulation codes, it is interesting to compare the concentrations in the dissolution solutions for a spent UOX fuel pellet and for an ECRIX-H pellet (Table 2).

Typically for a sample from a spent fuel dissolution solution, a $1 \mathrm{~mL}$ fraction after dilution by a factor of 1000 is allowable in an intermediate-level laboratory. In the case of the ECRIX-H dissolution solution, such a dilution would result in concentrations of about $35 \mu \mathrm{g} / \mathrm{L}$ for some elements such as $\mathrm{Nd}$. This implies that only about $35 \mathrm{ng}$ of matter would be transferred to the laboratory in a $1 \mathrm{~mL}$ solution sample. This quantity is too small for satisfactory quantification and repeatability, as TIMS measurements require at least $300 \mathrm{ng}$ of matter per element for an analysis comprising five 10-cycle blocks. Moreover, the Mg-rich matrix of the ECRIX-H pellets can hinder HPLC column separation by cation exchange, which is performed before TIMS analysis.

The dose rate of the initial ECRIX-H dissolution solution is due to the presence of fission products, but also to emitters that are generally found at ultralow concentrations in "typical" dissolution solutions: ${ }^{242} \mathrm{Am}$ and ${ }^{242} \mathrm{Cm}$.

We therefore sought to identify a protocol capable of addressing these two criteria: diminish the sample dose rate (i.e. decontaminate the solution of the main gamma emitters); and eliminate the $\mathrm{Mg}$ from the matrix.

\subsection{Isotopic analysis}

\subsubsection{Shielded cell separations}

Two separation routes were selected:

- Separation on Biorad AG1X8 resin to retain $\mathrm{U}$ and $\mathrm{Pu}$ (the major elements in ECRIX-H); $\mathrm{U}$ and $\mathrm{Pu}$ were then eluted separately;

- Separation on Eichrom DGA resin to retain the trivalent elements; this resin retains the lanthanides ( $\mathrm{Ln})$ and $\mathrm{Am} / \mathrm{Cm}$, but not $\mathrm{Mg}$ and the main gamma emitters such as Cs.

The optimized protocol shown in Fig. 2 calls for the following remarks:

- The protocol is applied directly to a sample of the dissolution solution (without prior dilution).

- No valence adjustment for $\mathrm{U}$ and $\mathrm{Pu}$ is implemented. In $\mathrm{HNO}_{3} 8 \mathrm{M}$ media, $\mathrm{Pu}$ is mainly $\mathrm{Pu}(\mathrm{IV})$ and $\mathrm{U}$ is mainly $\mathrm{U}(\mathrm{VI})$.

- Neutralization of fluoride by a concentrated aluminum nitrate solution (as in dissolution No. 2 in the nitric + hydrofluoric acid medium) is not used. $\mathrm{U}$ and $\mathrm{Pu}$ are partially complexed by fluoride and thus not retained on the AG1X8 column. Given its high concentration, traces of $U$ (and $\mathrm{Pu}$ in lesser extent) can be present in the Ln stream.

- However the valence adjustment by a ferrous sulfate solution and the fluoride neutralization by an aluminum nitrate solution would be possible without disturbing DGA performance. $\mathrm{Fe}(\mathrm{II}) / \mathrm{Fe}(\mathrm{III})$ and $\mathrm{Al}(\mathrm{III})$ have a low uptake by DGA $[8,9]$. We chose to minimize the addition 


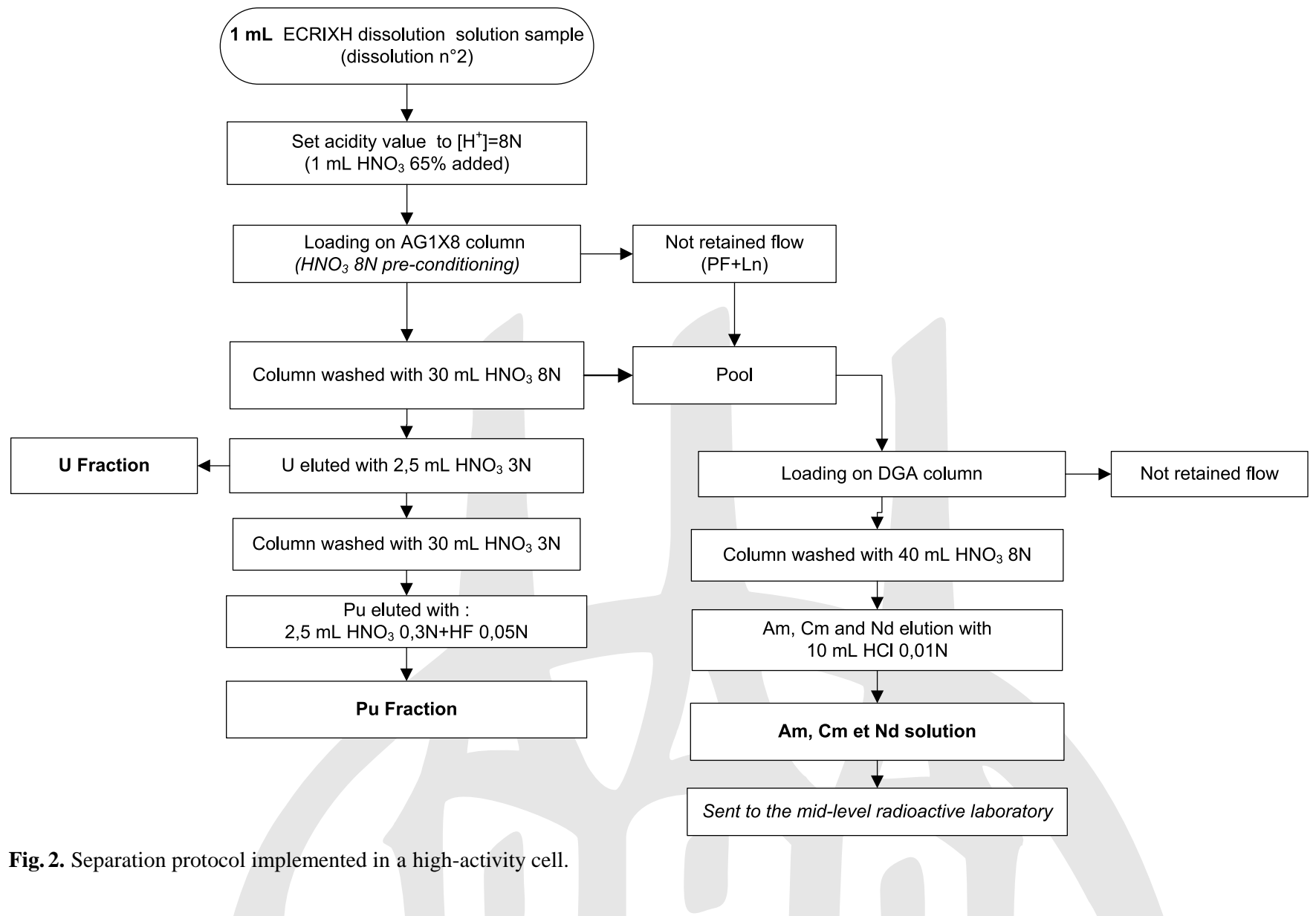

of reagents in hot cell in order to make easier the waste management.

- Analysis of the solution obtained by washing the AG1X8 column with $30 \mathrm{~mL}$ of $8 \mathrm{M} \mathrm{HNO}_{3}$ showed the importance of this step: the solution contained lanthanides.

- Some tests were realized to evaluate distribution coefficient of $\mathrm{Mg}$ on DGA resin in our experimental conditions. Thus, $0.2 \mathrm{~g}$ of DGA resin and $2 \mathrm{~mL}$ of $100 \mathrm{mg} / \mathrm{L}$ $\mathrm{Mg}(\mathrm{II})$ in $8 \mathrm{~N} \mathrm{HNO}_{3}$ were mixed during $5 \mathrm{~min}$. $\mathrm{Mg}$ was analyzed in the supernatant. These tests confirmed that $\mathrm{Mg}$ is not uptaked by DGA $[8,10]$.

For the ECRIX-H dissolution solutions the overall Am and $\mathrm{Nd}$ recovery efficiency of the protocol was estimated near $100 \%$ for both elements. The residual $\mathrm{Mg}$ in the $\mathrm{Ln}$ fraction was less than 1 wt. $\%$.

Gamma spectrometry measurements were used to estimate a ${ }^{137} \mathrm{Cs}$ decontamination factor exceeding $10^{4}$.

The different fractions obtained by this protocol could be transferred to the laboratory without restriction.

\subsubsection{Glove box separations}

In the laboratory, the sample containing $\mathrm{Am}, \mathrm{Cm}$ and $\mathrm{Nd}$ was again passed through AG1X8 resin to eliminate any residual Pu traces that could interfere with HPLC separation. The protocol is shown in Fig. 3.

A typical Am/Cm separation is illustrated in Fig. 4. The method used [11] was developed for solutions arising from the dissolution of spent UOX or MOX fuel after 5 to 10 years of cooling, in which the $\mathrm{Cm} / \mathrm{Am}$ activity ratios did not exceed $10: 1$ and the $\mathrm{Am} / \mathrm{Cm}$ mass ratios ranged from about $4: 1$ to $8: 1$. In the case of the ECRIX-H pellet dissolution solution, the $\mathrm{Cm} / \mathrm{Am}$ activity ratio was very high $(\sim 60: 1)$ whereas the $\mathrm{Am} / \mathrm{Cm}$ mass ratio was near $0.7: 1$. The difference between the solution compositions explains why the method used was unable to satisfactorily resolve the Am and $\mathrm{Cm}$ peaks for the ECRIX-H dissolution solution.

The decontamination of Cs was particularly effective: no radiometric signal was detected except for $\mathrm{Am}$ and $\mathrm{Cm}$.

Although $\mathrm{Cm}$ fractionation was performed without difficulty, the fraction containing $\mathrm{Am}$ (and $\mathrm{Cm}$ ) was reinjected in the HPLC column for a second purification.

The separation obtained is shown in Fig. 5. This time the resolution of the $\mathrm{Am}$ and $\mathrm{Cm}$ peaks was excellent and the fraction containing Am was pure. Resolution was calculated with

$$
R_{\mathrm{S}}=\frac{1.18\left(t_{2}-t_{1}\right)}{w_{\frac{1}{2}, 1}+w_{\frac{1}{2}, 2}}
$$

where $w_{1 / 2}$ was estimated by Peak Analyser module of Origin $^{\circledR}$ software. The values are reported in Table 3. Supposing that efficiency of radiometric detector was very close for $\mathrm{Am}$ and $\mathrm{Cm}$ counting, then their peak areas can be directly compared. Am and $\mathrm{Cm}$ specific activities were estimated to $2.6 \times 10^{12} \mathrm{~Bq} / \mathrm{g} \mathrm{Cm}$ and $4.9 \times 10^{10} \mathrm{~Bq} / \mathrm{g} \mathrm{Am}$ (isotopic results were used). From Fig. 5, peak areas ratio was about $A_{\mathrm{Cm}} / A_{\mathrm{Am}} \sim 2.3$. Thus mass ratio in the reinjected fraction was estimated to $m_{\mathrm{Cm}} / m_{\mathrm{Am}} \sim 4.3 \times 10^{-2}$. Cm mass represented about $4 \%$ of Am mass in reinjected fraction, and 


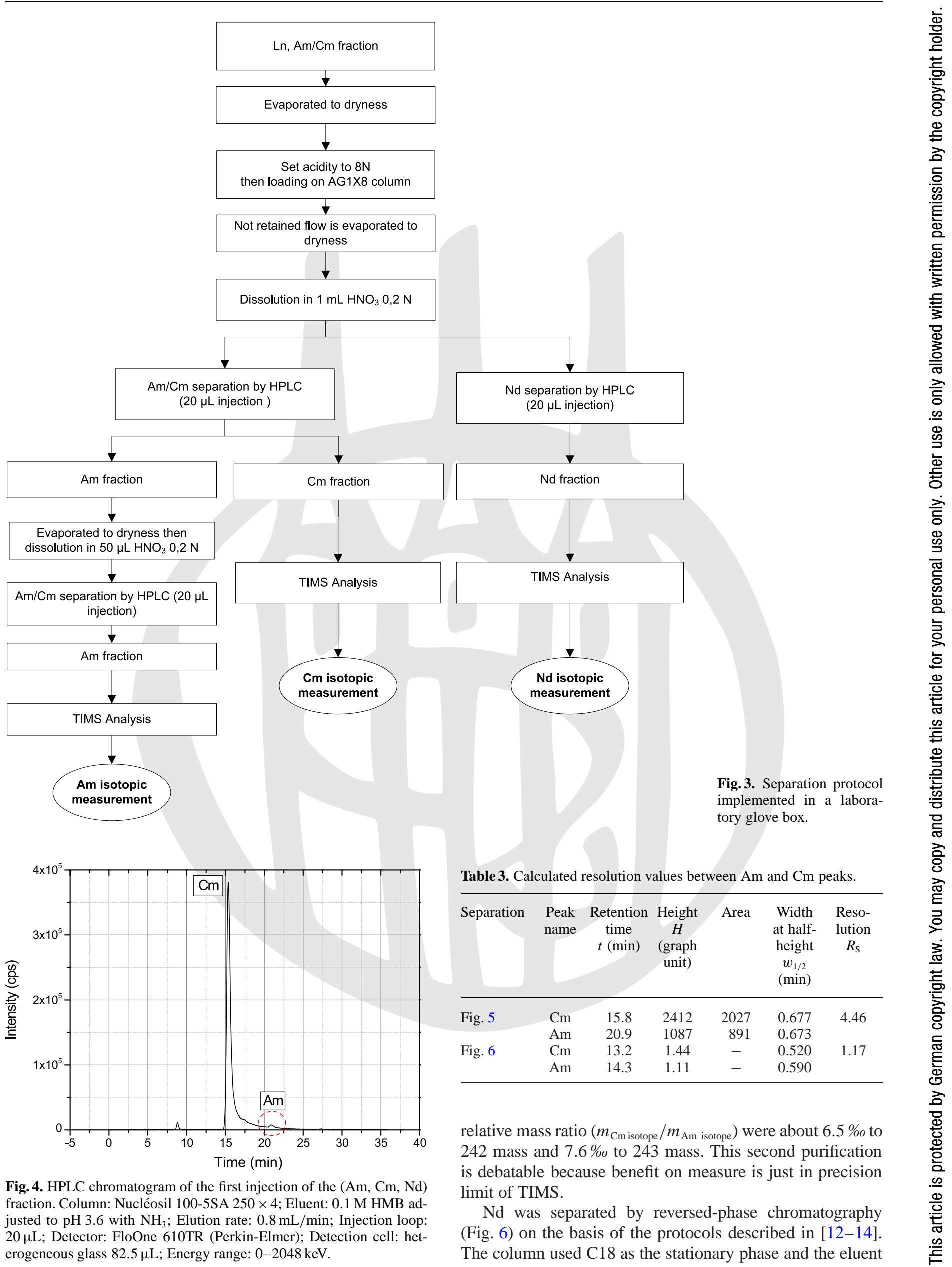




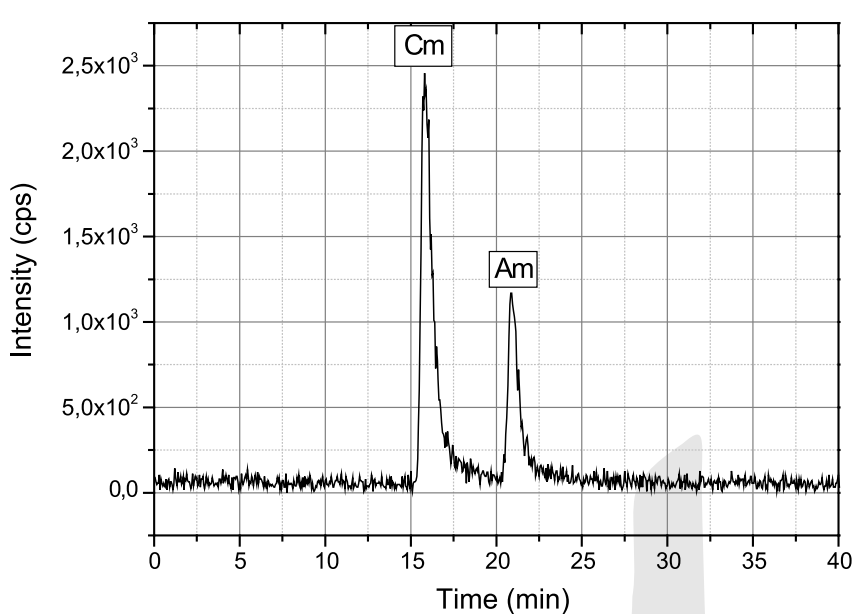

Fig. 5. HPLC chromatogram of the second injection of the $(\mathrm{Am} / \mathrm{Cm})$ fraction. Same operating conditions as in Fig. 4.

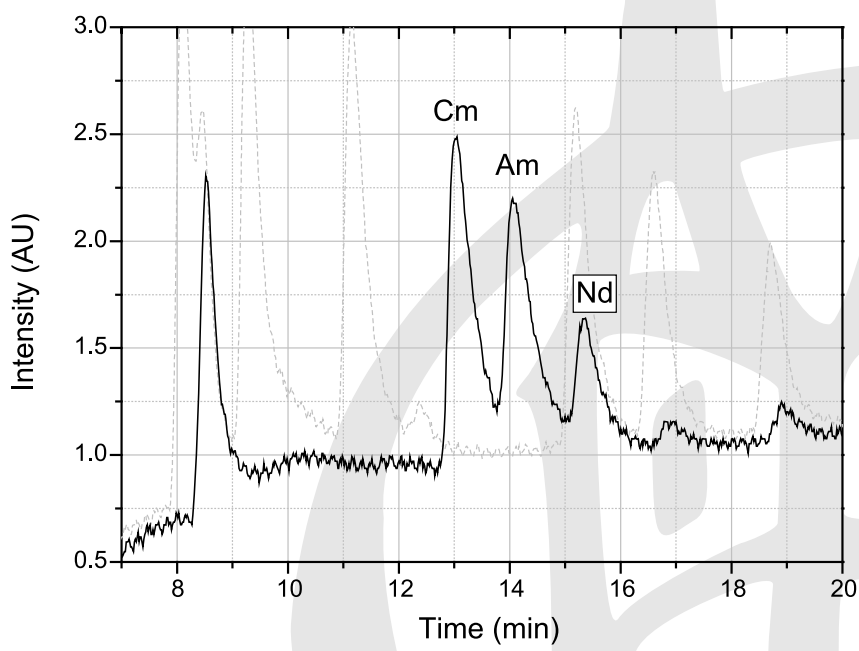

Fig. 6. Chromatogram of Ln separation from an ECRIX-H pellet dissolution solution after treatment (refer to text). The dotted line represents the injection of a surrogate Ln solution. Elution: 0.09-0.23 M HIBA in $20 \mathrm{~min}$ in the presence of $0.01 \mathrm{M}$ octanesulfonic acid adjusted to $\mathrm{pH} 3.7$ with $\mathrm{NH}_{3}$; Column: Vydac 201TP5415 $150 \times 4$ 46; Elution rate: $1 \mathrm{~mL} / \mathrm{min}$; Injection loop: $20 \mu \mathrm{L}$; Post-column derivation: PAR $0.05 \mathrm{~g} / \mathrm{L}$ in $1 \mathrm{M}$ acetic acidic $+2 \mathrm{M} \mathrm{NH}_{3}$. PAR flow rate: $0.3 \mathrm{~mL} / \mathrm{min}$. Detector: HR4000 (Ocean Optics) at $520 \mathrm{~nm}$; Detection cell: Z-flow with $1 \mathrm{~cm}$ optical path.

was $\alpha$-hydroxyisobutyric acid (HIBA) with $n$-octanesulfonic acid as a modifier. Detection was performed by spectrophotometry after adding a metallochromic complexing agent, PAR (4-(2-pyridylazo)resorcinol). Some parameters (elution rate, $\mathrm{pH}$ of eluent, gradient separation) were adjusted to optimize the resolution of $\mathrm{Nd}$ with $\mathrm{Ln}$ adjacent bands (potential isobaric interferences). Indeed $\mathrm{Nd}$ injected mass was more important (from 10 to 50 times) than one used in [12-14]. Direct fractionation of the flow detected by spectrophotometry would result in the presence of PAR in the sample and hinder the process of deposition on the filaments for TIMS analysis. Fractionation of part of the flow between the column outlet and the point of PAR addition was investigated. Under these conditions it is very difficult to sample exactly what is detected by spectrophotometry (different transit times for the two channels, allowance for the residence time and dead volume of the spectrophotometry cell, etc.). Given the difficulties involved in performing simultaneous fractionation with a detection channel, but considering the good repeatability of the separations, we decided to implement "blind" fractionation. After identifying the retention time of the peaks of interest in the first separation (Fig. 6), we conducted a second separation in which PAR was replaced by $10^{-3} \mathrm{M}$ nitric acid at the same flow rate.

The Nd and Am peaks were poorly resolved, but as Am does not create isobaric interference with $\mathrm{Nd}$, its presence does not hinder the isotopic determination of $\mathrm{Nd}$. $\mathrm{Mg}$ was eliminated from solution sufficiently that it did not interfere with the chromatogram and column performance. We can notice that $\mathrm{Am}$ and $\mathrm{Cm}$ are also separated by this method. Resolution was calculated for $\mathrm{Am}$ and $\mathrm{Cm}$ adjacent bands (Table 3). These results highlight that the quality of the separation between $\mathrm{Am}$ and $\mathrm{Cm}$ is better with the first method. However, an optimization study should allow to improve the resolution between $\mathrm{Am}$ and $\mathrm{Cm}$ of the second method. This work is already scheduled in our laboratory.

The preparation of injected sample was imposed by required mass quantity for TIMS measurement. Then, the calculus is in function of the least concentrated element to analyze in the original sample. The global irradiation of the injected sample can become important in some case and we have noticed that the used columns performances deteriorate with time. It can be necessary to carry out a little adjustment of some parameters to get a good separation back.

The isotopic compositions were determined for $\mathrm{Am}, \mathrm{Cm}$ and $\mathrm{Nd}$ (Tables 4 to 6). A scan of surrounding mass values confirmed absence of isobaric interference. The results of each dissolution are the average of two independent measurements.

The estimated uncertainties on the isotopic results were based on the known performance of the method, and on the experience acquired in the laboratory and on prior validation data. Isotopic reference standards are routinely measured to check the instrument response.

Table 4. Am isotopic assay (at. \%).

\begin{tabular}{|c|c|c|c|c|}
\hline & $\begin{array}{l}1^{\text {st }} \text { disso- } \\
\text { lution }\end{array}$ & $\begin{array}{l}2^{\text {nd }} \text { disso- } \\
\text { lution }\end{array}$ & $\begin{array}{l}\text { Neutronic } \\
3.5 \text { years } \\
\text { of cooling }\end{array}$ & $\begin{array}{l}\text { ulation after } \\
4 \text { years } \\
\text { of cooling }\end{array}$ \\
\hline 241 Am & $35.5 \pm 0.04$ & $34.17 \pm 0.03$ & 39.46 & 39.72 \\
\hline${ }^{242} \mathrm{Am}$ & $1.60 \pm 0.02$ & $1.55 \pm 0.02$ & 0.97 & 0.97 \\
\hline${ }^{243} \mathrm{Am}$ & $62.90 \pm 0.03$ & $64.28 \pm 0.06$ & 59.57 & 59.32 \\
\hline
\end{tabular}

Table 5. Cm isotopic assay (at. \%).

\begin{tabular}{|c|c|c|c|c|}
\hline & \multirow{2}{*}{$\begin{array}{l}1^{\text {st }} \text { disso- } \\
\text { lution }\end{array}$} & \multirow{2}{*}{$\begin{array}{l}2^{\text {nd }} \text { disso- } \\
\text { lution }\end{array}$} & \multicolumn{2}{|c|}{ Neutronic simulation after } \\
\hline & & & $\begin{array}{l}3.5 \text { years } \\
\text { of cooling }\end{array}$ & $\begin{array}{c}4 \text { years } \\
\text { of cooling }\end{array}$ \\
\hline${ }^{242} \mathrm{Cm}$ & $0.24 \pm 0.02$ & $0.25 \pm 0.01$ & 0.30 & 0.14 \\
\hline${ }^{243} \mathrm{Cm}$ & $11.45 \pm 0.06$ & $11.34 \pm 0.06$ & 6.65 & 6.64 \\
\hline${ }^{244} \mathrm{Cm}$ & $69.94 \pm 0.07$ & $70.02 \pm 0.07$ & 69.17 & 68.86 \\
\hline${ }^{245} \mathrm{Cm}$ & $15.11 \pm 0.08$ & $15.06 \pm 0.08$ & 18.35 & 18.70 \\
\hline${ }^{246} \mathrm{Cm}$ & $3.13 \pm 0.03$ & $3.17 \pm 0.02$ & 5.26 & 5.38 \\
\hline${ }^{247} \mathrm{Cm}$ & $0.14 \pm 0.01$ & $0.14 \pm 0.01$ & 0.22 & 0.23 \\
\hline${ }^{248} \mathrm{Cm}$ & $<0.05$ (DL) & $<0.05$ (DL) & 0.04 & 0.04 \\
\hline
\end{tabular}


Table 6. Nd isotopic assay (at. \%)

\begin{tabular}{lcccc}
\hline & $\begin{array}{c}1^{\text {st }} \text { disso- } \\
\text { lution }\end{array}$ & $\begin{array}{c}2^{\text {nd }} \text { disso- } \\
\text { lution }\end{array}$ & $\begin{array}{c}\text { Neutronic simulation after } \\
3.5 \text { years } \\
\text { of cooling }\end{array}$ & $\begin{array}{c}\text { 4 years } \\
\text { of cooling }\end{array}$ \\
\hline${ }^{142} \mathrm{Nd}$ & $0.74 \pm 0.04$ & $0.95 \pm 0.10$ & 0.85 & 0.84 \\
${ }^{143} \mathrm{Nd}$ & $19.97 \pm 0.02$ & $19.69 \pm 0.10$ & 18.69 & 18.65 \\
${ }^{144} \mathrm{Nd}$ & $27.53 \pm 0.03$ & $27.58 \pm 0.14$ & 28.94 & 29.07 \\
${ }^{145} \mathrm{Nd}$ & $15.19 \pm 0.02$ & $15.09 \pm 0.08$ & 14.89 & 14.86 \\
${ }^{146} \mathrm{Nd}$ & $18.97 \pm 0.02$ & $19.08 \pm 0.10$ & 19.22 & 19.19 \\
${ }^{147} \mathrm{Nd}$ & $<0.1(\mathrm{DL})$ & $<0.1(\mathrm{DL})$ & 0.00 & 0.00 \\
${ }^{148} \mathrm{Nd}$ & $10.81 \pm 0.01$ & $10.86 \pm 0.05$ & 11.00 & 10.99 \\
${ }^{150} \mathrm{Nd}$ & $6.78 \pm 0.03$ & $6.76 \pm 0.07$ & 6.41 & 6.40 \\
\hline
\end{tabular}

\subsection{Quantitative analysis}

Analysis by isotopic dilution was chosen for quantitative determination to ensure highest possible accuracy. Isotopic dilutions were carried out on samples of the high-activity dissolution solution. Source tracing takes into account possible variations in the dissolution solution (concentration by evaporation, for example), as well as the efficiency of the different separation steps implemented prior to TIMS analysis.

Isotope dilution is subject to certain conditions, however:

- Mixing between the tracer and the sample must result in ideal chemical and isotopic homogeneity (same valence state and same physical state).

- No chemical treatment of the sample/tracer mixture must affect isotopic fractionation.

The tracers were selected and adjusted so that after addition the major isotope in the tracer was present in the same proportion as the major isotope in the sample (Table 7). Prior sample dilution by a factor of 250 was necessary to trace $\mathrm{Cm}$ because its concentration was too high with respect to the available tracer concentration.

All dilutions were carried out by weighing. Solution tracing was performed twice. The separation protocols were identical to those used for isotopic analysis.

The results calculated from the general equation for isotope dilution are expressed as a mass concentration of the element in the irradiated pellet dissolution solution before or after dilution. Based on the mass of the final filtered dissolution solution (from which the analysis samples were taken), the dissolved pellet mass, and the dilution factor, the results are expressed in milligrams per gram of initial heavy metal $\left(\mathrm{mg} / \mathrm{g}_{\mathrm{iHM}}\right)$ in Table 8.

The uncertainties were calculated by applying the law of propagation of uncertainty. Only the uncertainty on the

Table 7. Tracers and isotopic ratios obtained in the sample-tracer mixture.

\section{Major isotope in tracer Estimated isotopic ratio} in sample + tracer solution

$\begin{array}{ll}{ }^{241} \mathrm{Am} & 241 / 243=0.90 \\ { }^{145} \mathrm{Nd} & 145 / 144=1.22 \\ { }^{248} \mathrm{Cm} & 248 / 244=1.12\end{array}$

Table 8. Concentration of heavy nuclides in the pellets at the end of irradiation: measured and calculated values.

\begin{tabular}{lccc}
\hline Element & \multicolumn{3}{c}{ Concentration $\left(\mathrm{mg} / \mathrm{g}_{\mathrm{iнm}}\right)$} \\
\cline { 2 - 4 } & $\begin{array}{c}\text { Measurement } \\
\text { after 3.5-4 } \\
\text { years of } \\
\text { cooling }\end{array}$ & $\begin{array}{c}\text { Neutronic } \\
\text { simulation } \\
\text { after 3.5 years } \\
\text { of cooling }\end{array}$ & $\begin{array}{c}\text { Neutronic } \\
\text { simulation } \\
\text { after 4 years } \\
\text { of cooling }\end{array}$ \\
\hline $\mathrm{Am}$ & $63.4 \pm 0.81$ & 79.1 & 79.4 \\
$\mathrm{Cm}$ & $99.2 \pm 5.3$ & 96.7 & 95.2 \\
$\mathrm{Nd}$ & $29.3 \pm 0.29$ & 34.7 & 34.7 \\
\hline
\end{tabular}

initial Am content of the pellet (16.65 wt. \%) was disregarded.

The Cm content was also determined by alpha spectrometry. Based on the measured isotopic composition, the $\mathrm{Cm}$ concentration was estimated at $98.7 \pm 11.7 \mathrm{mg} / \mathrm{g}_{\text {iHM }}$. This result is very good agreement with the value indicated in Table 8 .

On the basis of the results in Table 8, the dissolved pellet mass, and the initial Am mass ratio of $16.65 \%$, the Am transmutation efficiency is estimated at $93.7 \%$.

\section{Conclusion}

Two irradiated ECRIX-H pellets were dissolved in view of two distinct objectives.

Concerning the reprocessability of pellets containing americium, a large quantity of insolubles can be observed (about $10 \mathrm{wt}$. \% of the initial fuel).

The second objective was addressed by the dissolution of a pellet in nitric + hydrofluoric acid to characterize some elements of interest (Am, $\mathrm{Cm}$ and $\mathrm{Nd}$ ) in order to consolidate the evolution codes and determine the fission and transmutation rates.

Separation protocols were implemented in a high-activity cell to diminish the sample dose rate while transferring sufficient quantities of the elements to be measured. Additional separations were then performed in the laboratory.

Isotopic and quantitative analyses were carried out for $\mathrm{Am}, \mathrm{Cm}$ and $\mathrm{Nd}$. The values obtained were in very good agreement with the estimates given by the evolution code.

The Am transmutation rate was estimated experimentally at 93.7 at. \%, which is slightly higher than the value obtained by neutronic simulation i.e. 92.6 at. \%. The same trend was also observed by means of radial EPMA analysis on pellets [3].

Dissolution tests and analysis on two $\mathrm{UO}_{2}$ pellets irradiated in the same pin will be performed later to quantify precisely the neutron fluence accumulated by the $\mathrm{Am}_{1.62} / \mathrm{MgO}$ pellets and reajust the simulation code calculation.

Acknowledgment. The authors would like to thank Electricité de France (EDF) for its financial support.

\section{References}

1. Béjaoui, S., Lamontagne, J., Bonnerot, J. M., Brunon, E.: In: Proceedings of Global 2009. Paris, France (2009), pp. 2104-2115.

2. Béjaoui, S., Lamontagne, J., Esbelin, E, Bonnerot, J. M., Brunon, E., Bourdot, P.: J. Nucl. Mater. 415, 158 (2011). 
3. Lamontagne, J., Béjaoui, S., Hanifi, K., Valot, Ch., Loubet, L.: J. Nucl. Mater. 413, 134 (2011).

4. Lamontagne, J., et al.: J. Nucl. Mater., submitted for publication (2013).

5. Vidal, J.-M., Groullier, J.-P., Launay, A., Berthion, Y., Marc, A., Toubon, H.: In: Proceedings of WM'06 Conference, Tucson, USA (2006).

6. Roque, B., Thiollay, N., Marimbeau, P., Barreau, A., Tsilanzara, A., Garzenne, C., Marcel, F.: In: Proceedings of International Conference on Reactor Physics Safety and High-Performance Computing, PHYSOR 2002, Seoul, Korea, 7-10 October 2002, CD, ISBN: 0894486721.

7. Crozet, M., Guigue, M.: Radiochim. Acta 95, 629-635 (2007).
8. Horwitz, E. P., McAlister, D. R., Bond, A. H., Barrans, R. E.: Solv. Extr. Ion Exch. 23, 319 (2005)

9. Horwitz, E. P., McAlister, D. R., Thakkar, A. H.: Solv. Extr. Ion Exch. 26, 12 (2008).

10. Pourmand, A., Dauphas, N.: Talanta 81, 741 (2010).

11. Chartier, F., Aubert, M., Pilier, M.: Fresenius J. Anal. Chem. 364, 320 (1999).

12. Knight, C. H., Cassidy, R. M., Recoskie, B. M., Green, L. W.: Anal. Chem. 56, 474 (1984).

13. Barkley, D. J., Blanchette, M., Cassidy, R. M., Elchuk, S.: Anal. Chem. 58, 2222 (1986).

14. Tsakanika, L. V., Ochsenkühn-Petropoulou, M. T., Mendrinos, L. N.: Anal. Bioanal. Chem. 379, 796 (2004). 